Original Paper http://ajol.info/index.php/ijbcs http://indexmedicus.afro.who.int

\title{
Impact of eight isolates of Rice Yellow Mottle Virus (RYMV) from Gagnoa (Côte d'Ivoire) on rice (Oryza sp) cultivars production
}

\author{
Dago Faustin SOKO ${ }^{1 *}$, Koutoua AYOLIE ${ }^{1}$, N'dodo Boni Clovis KOFFI', \\ Dolou Charlotte TONESSIA ${ }^{1}$, Yacouba SERE ${ }^{2}$, Tanoh Hilaire KOUAKOU ${ }^{3}$ \\ and Séverin $\mathrm{AKE}^{4}$ \\ ${ }^{I}$ Université Jean Lorougnon Guédé, Laboratoire de Physiologie et de Pathologie Végétale, \\ BP 150 Daloa, Côte d'Ivoire. \\ ${ }^{2}$ Centre du Riz pour l'Afrique (AfricaRice), 01 BP 2551 Bouaké 01, Côte d'Ivoire. \\ ${ }^{3}$ Université Nangui Abrogoua, Laboratoire de Biologie et d'Amélioration des Productions Végétales, \\ 02 BP 801 Abidjan 02, Côte d'Ivoire. \\ ${ }^{4}$ Université Félix Houphouët-Boigny de Cocody, Laboratoire de Physiologie Végétale, \\ 22 BP 552 Abidjan 22, Côte d'Ivoire \\ *Corresponding author; E-mail: fsoko2000@yahoo.com ; Tel: +225 47618785
}

\begin{abstract}
Rice yellow mottle virus, of the genus Sobemovirus, causes a major disease in Africa especially in the lowland and irrigated rice ecologies. Yield losses due to the virus were estimated between 5-100\% and depend on genotype. This study, conducted in a screen house, aimed at assessing the impact of eight RYMV isolates from a restrictive environment Gagnoa (Côte d'Ivoire) on 10 differential rice varieties. The plants were inoculated manually by rubbing the leaves from the leaf base to the tip with fingers moistened with inoculum. Virus content and percentage yield reduction of different rice cultivars have been assessed. Result showed that an important variability was observed in the reaction of different rice genotypes infected by different isolates of RYMV. In susceptible cultivars Bouaké 189, PNA647F4-56 and H232-44-1-1 virus content and yield reduction varied respectively from 0.08 to 0.264 and 20 to $95 \%$. In resistant cultivars, Gigante, Lac 23, Morobérékan and Faro 11, virus content and yield reduction varied respectively from 0.03 to 0.188 and 5 to $17 \%$. The lowest virus content and yield reduction was observed with the isolate 7 from upland rice. The significant difference in the interaction observed between the different genotypes of rice and isolates of RYMV suggested the existence of different strains of RYMV within a restrictive environment.
\end{abstract}

(C) 2015 International Formulae Group. All rights reserved.

Keywords: AfricaRice, Sobemovirus, aggressive, virus content, yield reduction, virulence.

\section{INTRODUCTION}

Rice has long been an important staple food for many traditional rice growing communities. To reduce malnutrition in developing country, intensification of rice crop using good production varieties is necessary. Unfortunately, the varieties are very susceptible to many pathogens such of virus, fungal and bacterial. Among these diseases, Rice yellow mottle virus, of the genus Sobemovirus, causes a major disease in Africa (Kouassi et al., 2005; Sere et al., 2008a; Ochola and Tusiime, 2011a) especially in the lowland and irrigated rice ecologies 
(Banwo et al., 2004). Yield loss due to the virus was estimated between $17-100 \%$ and depends on genotype (Onwughalu et al., 2011) and time of infection (Onwughalu et al., 2010). The virus has a narrow host range restricted to the cultivated rice species, Oryza sativa and $O$. Glaberrima, and a few grasses (Allarangaye et al., 2007). A few rice cultivars exhibit a high resistance to RYMV characterized by an absence of symptoms and no viral detection by ELISA (Ndjiondjop et al., 2001).

The RYMV is mechanically transmissible by insects, genus Chrysomelidea (Abo et al., 2000, Nwilene et al., 2009). These insects play a major role in the virus transmission. Traore et al. (2008) found an abiotic transmission by soil, seedbed, and cultural. RYMV disease is characterized by mottle and yellowing symptoms of varying intensity depending on genotype and time after infection (Soko et al., 2010 ; Onwughalu et al., 2010, 2011). Others symptoms observed on infected plants are stunted, reduced tillering, pour panicle exertion and grain discoloration (Gnanamanickam, 2009). Natural and transgenic sources of resistance were reported (Sorho et al., 2005). Many studies reported the existence of different strains of the virus (Sorho et al., 2005; Amancho et al., 2009 ; Onasanya et al., 2012; Issaka et al., 2011). Many resistance genes were described and a major gene of resistance against RYMV was identified in the $O$. sativa resistance variety Gigante (Albar et al., 2006). A new resistance gene was recently reported as RYMV2 in Tog5672 and Tog5691 (Tiemele et al., 2010). Different serotypes (Sere et al., 2007) and pathotypes of RYMV isolates are known to exist (Onasanya et al., 2004 ; Ochola and Tsiime, 2011a).

The study was undertaken to investigate the impact of eight isolates of rice yellow mottle virus from Gagnoa, Côte d'Ivoire (west-Africa) on Africa Rice differential rice varieties production.

\section{MATERIALS AND METHODS Materials}

Ten AfricaRice differential rice cultivars were used for this study (Table 1).
Virus isolates: eight isolates of rice yellow mottle virus used for this study were originated from different rice crops in Gagnoa (Côte d'Ivoire) (Table 2). They were obtained from plant pathology unit, AfricaRice.

\section{Experimental design}

The ten rice cultivars were potted and raised in a screen house at AfricaRice in a split plot design with three replicates, in which the main plot was attributed to RYMV. Each variety is transplanted on six poquets among which two being control are not inoculated. Seedlings were thinned to three plants per pot. The space between replication is $50 \mathrm{~cm}$, and $40 \mathrm{~cm}$ between plot and $10 \mathrm{~cm}$ between varieties on the line. The trial was fertilized with NPK (10-18-18) at the rate of $120 \mathrm{kgN} / \mathrm{ha}(50 \mathrm{kgN} / \mathrm{ha}$ were brought at tillering and $50 \mathrm{kgN} / \mathrm{ha}$ at panicle initiation) with watering and weeding carried when necessary.

\section{Inoculum preparation and plant infection}

Each isolate was first propagated in the susceptible rice variety Bouake 189 by mechanical inoculation of 21 days old plant in screen house. Three weeks after, a mixture of $60 \mathrm{~g}$ of infected leaves from each isolate were harvested and ground, using sterile mortars and pestles in $10 \mathrm{ml}$ of double distilled water. The inoculum was then rubbed onto leaves of the ten differential rice cultivars from the leafbase to the tip with finger moistened with prepared inoculum after 14 days postemergence (most plant had achieved a 3 leaf stage).

\section{Virus content assessment}

Virus content was assessed using different sample of infected leaves 28 days after inoculation with IACP (Indirect antigene coated plate) - ELISA method (Clark et Adams 1977). Absorbance at wavelength 405 $\mathrm{nm}$ was performed after $1 \mathrm{~h}$ of substrate incubation

\section{Grain yield evaluation}

Rice was harvested after five months and yield component of healthy plant and infected plant was determined after drying to 
constant weight. Yield loss was evaluated using the following formula:

\section{PYR $=[($ GYI-GYH) $\times 100] / G Y I$}

PYR: Percentage of grain yield reduction

GYH: Grain yield production with healthy plant

GYI: Grain yield production with infected plant

\section{Statistical analysis}

Experiments were performed using a split plot design. Viral content (optical density) and percentage yield reduction were subjected to analysis of variance (ANOVA) using IRRISTAT version 5.1 statistical software and differences between means were compared using Duncan multiple range test (DMRT). Differences at 5\% were considered as significant.

\section{RESULTS}

\section{Varietal reaction to RYMV isolates} accumulation

Different levels of viral accumulation are presented in Table 3. Considerable diversity was observed in the reaction of the ten rice cultivars to 8 isolates in terms of virus content. Virus accumulation varies with varieties and isolates. Analysis of variance showed significant $(p<0.01)$ effect of varieties, isolates and an interaction between varieties and isolates (Table 3). These results showed that RYMV isolates used in this study differ by their virulence and the varieties by their vertical resistant. ELISA test showed high viral content in susceptible rice cultivars Bouaké 189, PNA647F4-56, H234-18-1-1-1 and H232-44-1-1. Virus content observed in the cultivar Bouaké 189 ranged from 0.148 for isolate 5 to 0.310 for isolate 4. Considering PNA647F4-56, isolate 4 showed the lowest virus content. Virus content observed in the susceptible rice cultivars H232-44-1-1 ranged from 0.177 for isolate 7 to 0.333 for isolate 8 (Table 4). These results showed that virus content depends on rice cultivars genotype. The highest level of virus content was observed when the cultivar H232-44-1-1 was infected by isolate 8 from Odienné, considered as a control (Table 4). The rice cultivars Faro11, Morobérékan and IR4768615-1-1 and Lac 23 showed the lowest content of RYMV isolates. The rice cultivar Faro 11 could not be infected by isolate 2 and 7 and Morobérékan is only infected by isolate 1, 2 and 8 with a virus content equal to the threshold of positivity (0.08). The cultivars IR47686-15-1-1 is only infected by isolates 1 and 6 with a viral content mean of 0.155 . The cultivar Gigante has no virus content and is considered as immune ( $\mathrm{DO}<0.05)$ and highly resistant to all isolates. Considering all isolates, isolate 8 has the highest virus content and affects $80 \%$ of all varieties and isolate 7 presents the lowest viral content. This isolate infects only $50 \%$ of all the varieties.

\section{Percentage yield reduction due to RYMV \\ Considerable diversity was observed in} the reaction of the ten rice cultivars to 8 isolates in terms of yield reduction. Analysis of variance for the percentage of yield reduction showed significant $(\mathrm{p}<0.01)$ effect of varieties, isolates and an interaction between varieties and isolates (Table 3). These results showed that RYMV isolates used in this study differ by their virulence and the varieties by their vertical resistant. Globally, the percentage of yield reduction of each rice cultivars varied considerably with the RYMV isolate (5 to 95\%) (Table 5). The highest yield losses were observed in susceptible varieties Bouaké 189, PNA647F456, H234-18-1-1-1 and H232-44-1-1 varying from $20 \%$ to $95 \%$ ) when infected by all isolates. The highest yield losses were observed in susceptible Bouaké 189 (94.40\%) when infected by isolate 6 . The lowest yield losses were obtained with isolate 7 in all rice cultivars and were estimated to $(27.90 \%)$ suggesting that this isolate is less aggressiveness. Globally, the isolates 1 and 8 were more aggressive. The rice cultivars Lac 23, ITA235, FARO11 (OS6), MOROBEREKAN, IR47686-15-1-1, are characterized par low yield reduction when infected by all isolates. Yield reduction varied from 5 to $16 \%$. 
Table 1: Characteristics of different rice cultivars used in this study.

\begin{tabular}{lcc}
\hline Varieties & Varietal reaction & Origin \\
\hline IR47686-15-1-1 & Resistant & IRRI \\
H234-18-1-1-1 & Positive of Elisa & Argentina \\
ITA235 & Resistant/susceptibility & IITA/Nigeria \\
PNA647F4-56 & Resistant/susceptibility & Peru \\
BOUAKE189 & susceptibility & Côte d'Ivoire \\
H232-44-1-1 & susceptibility & Argentina \\
FARO 11 & Resistant/susceptibility & Nigeria/DRC \\
GIGANTE (tete) & Resistant & Asia \\
Lac 23 & Resistant/susceptibility & Liberia \\
MOROBEREKAN & Resistant/susceptibility & Côte d'Ivoire \\
\hline \multicolumn{2}{c}{ DRC: Democratic Republic of Congo. }
\end{tabular}

Table 2: Characteristic of RYMV isolates and their naturel host.

\begin{tabular}{lccc}
\hline Code & Isolates & Samples locality & Host \\
\hline SP & ISO1 & Site clé prolongement & Sacciolepis africana \\
RM & ISO2 & Route Mahiboua & Rice \\
SE & ISO3 & Site clé extention & Rice \\
RA & ISO4 & Route Abidjan & Rice \\
CI & ISO5 & CRNA ex Idessa & Rice \\
AF & ISO6 & Afridougou & Rice \\
GP & ISO7 & Gagnoa Plateau & Rice \\
OD & ISO8 & Odienné & Rice \\
\hline
\end{tabular}

Table 3: Analysis of variance for RYMV accumulation and percentage yield reduction.

\begin{tabular}{cccccccc}
\hline Source & \multicolumn{4}{c}{ Viral accumulation } & \multicolumn{3}{c}{ \% Yield reduction } \\
\cline { 2 - 8 } of variation & DF & SS & MS & F & SS & MS & F \\
\hline Rep & 2 & 0.00038 & 0.00019 & $1.41 \mathrm{~ns}$ & 16.20 & 8.10 & $1.20 \mathrm{~ns}$ \\
Varieties (V) & 9 & 0.97 & 0.11 & $423^{* *}$ & 137789 & 15309 & $2274^{* *}$ \\
Error (a) & 18 & 0.0047 & 0.00026 & & 121.4 & 6.74 & \\
Isolates (I) & 7 & 0.084 & 0.012 & $85.70^{* *}$ & 7772 & 1110.3 & $165^{* *}$ \\
VXI & 63 & 0.047 & 0.00075 & $5.35^{* *}$ & 11562 & 183.5 & $27.3^{* *}$ \\
Error (b) & 140 & 0.0189 & 0.00014 & & 942.3 & 673 & \\
\hline Total & 239 & \multicolumn{7}{c}{} \\
\hline ** = significant at 1\% level; ns = not significant; DF: degree of freedom, SS: sum of square; MS: mean square; Rep: \\
replicate.
\end{tabular}


Table 4: Analysis of mean comparison for RYMV accumulation in varieties.

\begin{tabular}{|c|c|c|c|c|c|c|c|c|c|}
\hline \multirow[b]{2}{*}{ Varieties } & \multicolumn{8}{|c|}{ RYMV isolates } & \multirow[b]{2}{*}{$\begin{array}{c}\text { V. } \\
\text { Mean }\end{array}$} \\
\hline & ISO1 & ISO2 & ISO3 & ISO4 & ISO5 & ISO6 & ISO7 & ISO8 & \\
\hline BOUAKE189 & $0.264 \mathbf{a}$ & $0.239 b$ & $0.210 \mathbf{b}$ & $0.310 \mathbf{a}$ & $0.148 d$ & $0.218 \mathbf{a}$ & $0.089 \mathbf{b}$ & $0.281 \mathbf{b}$ & 0.219 \\
\hline PNA647F4-56 & $0.182 d$ & $0.274 \mathbf{a}$ & $0.183 \mathrm{c}$ & $0.130 \mathrm{c}$ & $0.203 \mathbf{b}$ & $0.217 \mathbf{a}$ & $0.189 \mathbf{a}$ & $0.225 \mathrm{c}$ & 0.200 \\
\hline H232-44-1-1 & $0.204 c$ & $0.273 \mathbf{a}$ & $0.258 \mathbf{a}$ & $0.195 \mathbf{b}$ & $0.226 \mathbf{a}$ & $0.208 \mathbf{a}$ & $0.177 \mathbf{a}$ & $0.333 \mathbf{a}$ & 0.234 \\
\hline H234-18-1-1-1 & $0.228 \mathbf{b}$ & $0.147 \mathrm{c}$ & $0.153 d$ & $0.139 \mathrm{c}$ & $0.136 \mathbf{d}$ & $0.185 b$ & $0.073 \mathbf{c}$ & $0.192 d$ & 0.157 \\
\hline LAC23 & $0.044 \mathbf{f}$ & $0.066 \mathbf{f}$ & $0.060 \mathbf{e}$ & $0.109 d$ & $0.09 \mathrm{e}$ & $0.038 \mathrm{e}$ & $0.06 \mathbf{c}$ & $0.049 \mathrm{~g}$ & 0.064 \\
\hline ITA235 & $0.180 d$ & $0.084 \mathrm{e}$ & $0.094 \mathbf{e}$ & $0.188 \mathbf{b}$ & $0.094 \mathbf{e}$ & $0.191 \mathbf{b}$ & $0.094 \mathbf{b}$ & $0.170 \mathbf{e}$ & 0.137 \\
\hline FARO11(OS6) & $0.161 \mathrm{e}$ & $0.063 \mathbf{f}$ & $0.080 \mathbf{e}$ & $0.126 \mathrm{~cd}$ & $0.180 \mathrm{c}$ & $0.108 d$ & $0.071 \mathrm{c}$ & $0.155 \mathbf{e}$ & 0.118 \\
\hline MOROBEREKAN & $0.086 \mathbf{f}$ & $0.109 d$ & $0.062 \mathbf{e}$ & $0.054 \mathbf{f}$ & $0.073 \mathbf{e}$ & $0.042 \mathrm{e}$ & $0.046 \mathbf{d}$ & $0.080 \mathbf{f}$ & 0.069 \\
\hline IR47686-15-1-1 & $0.160 \mathbf{e}$ & $0.086 \mathbf{e}$ & $0.147 \mathbf{d}$ & $0.091 \mathbf{e}$ & $0.099 \mathbf{e}$ & $0.150 \mathrm{c}$ & $0.086 \mathbf{b}$ & $0.068 \mathbf{f}$ & 0.111 \\
\hline GIGANTE (tete) & $0.031 \mathbf{f}$ & $0.039 \mathrm{~g}$ & $0.043 \mathbf{f}$ & $0.050 \mathbf{f}$ & $0.036 \mathbf{f}$ & $0.039 \mathbf{e}$ & $0.049 \mathrm{~d}$ & $0.041 \mathrm{~g}$ & 0.042 \\
\hline Mean (isolate) & 0.154 & 0.138 & 0.139 & 0.140 & 0.128 & 0.139 & 0.093 & 0.160 & \\
\hline
\end{tabular}

Table 5: Analysis of means comparison for percentage yield reduction due to RYMV.

\begin{tabular}{lcccccccccc}
\hline \multirow{2}{*}{ Varieties } & \multicolumn{8}{c}{ RYMV isolates } & \\
\cline { 2 - 9 } & ISO1 & ISO2 & ISO3 & ISO4 & ISO5 & ISO6 & ISO7 & ISO8 & $\begin{array}{c}\text { V. } \\
\text { Mean }\end{array}$ \\
\hline BOUAKE189 & $91.80 \mathbf{a}$ & $78.4 \mathbf{a}$ & $79.40 \mathbf{a}$ & $72.33 \mathbf{a}$ & $76,27 \mathbf{a}$ & $94.40 \mathbf{a}$ & $27.90 \mathbf{a}$ & $88.17 \mathbf{a}$ & 76.08 \\
PNA647F4-56 & $66.70 \mathbf{b}$ & $63.13 \mathbf{b}$ & $63.00 \mathbf{b}$ & $59.77 \mathbf{b}$ & $64,50 \mathbf{b}$ & $58.17 \mathbf{b}$ & $23.30 \mathbf{b}$ & $71.93 \mathbf{b}$ & 58.81 \\
H232-44-1-1 & $51.33 \mathbf{c}$ & $37.50 \mathbf{d}$ & $31.50 \mathbf{c}$ & $34.60 \mathbf{c}$ & $42,63 \mathbf{c}$ & $56.93 \mathbf{b}$ & $19.63 \mathbf{b}$ & $49.87 \mathbf{c}$ & 40.50 \\
H234-18-1-1-1 & $51.13 \mathbf{c}$ & $42.90 \mathbf{c}$ & $34.17 \mathbf{c}$ & $31.63 \mathbf{c}$ & $28,83 \mathbf{d}$ & $51.07 \mathbf{c}$ & $30.70 \mathbf{a}$ & $44.47 \mathbf{d}$ & 39.36 \\
LAC23 & $16.13 \mathbf{d}$ & $11.47 \mathrm{e}$ & $15.80 \mathbf{d}$ & $9.63 \mathbf{d}$ & $13,87 \mathbf{e}$ & $14.73 \mathbf{d}$ & $6.73 \mathbf{c}$ & $13.40 \mathbf{e}$ & 12.72 \\
ITA235 & $9.27 \mathbf{e}$ & $10.93 \mathbf{e}$ & $10.67 \mathbf{e}$ & $12.83 \mathbf{d}$ & $12,87 \mathbf{e}$ & $9.97 \mathbf{e}$ & $6.73 \mathbf{c}$ & $11.57 \mathbf{e}$ & 10.60 \\
FARO11(OS6) & $10.93 \mathbf{e}$ & $9.93 \mathbf{e}$ & $7.30 \mathbf{e}$ & $7.07 \mathbf{e}$ & $8,33 \mathbf{f}$ & $9.23 \mathbf{e}$ & $4.93 \mathbf{c}$ & $10.03 \mathbf{e f}$ & 8.52 \\
MOROBEREKAN & $7.03 \mathbf{e}$ & $4.47 \mathbf{e}$ & $7.63 \mathbf{e}$ & $5.37 \mathbf{e}$ & $6.37 \mathbf{f}$ & $8.47 \mathbf{e}$ & $5.13 \mathbf{c}$ & $7.07 \mathbf{f}$ & 6.57 \\
IR47686-15-1-1 & $9.33 \mathbf{e}$ & $7.70 \mathbf{e}$ & $6.87 \mathbf{e}$ & $7.13 \mathbf{e}$ & $8,37 \mathbf{f}$ & $10.47 \mathbf{e}$ & $5.47 \mathbf{c}$ & $10.87 \mathbf{e f}$ & 8.27 \\
GIGANTE (tete) & $8.40 \mathbf{e}$ & $6.17 \mathbf{e}$ & $7.93 \mathbf{e}$ & $6.13 \mathbf{e}$ & $5,70 \mathbf{f}$ & $7.63 \mathbf{e}$ & $5.47 \mathbf{c}$ & $7.97 \mathbf{e f}$ & 6.92 \\
Mean (isolate) & 32.21 & 27.36 & 26.47 & 24.65 & 26,77 & 32.11 & 13.60 & 31.53 & \\
\hline
\end{tabular}

ISO $:$ isolate, ISO1 $=\mathrm{SP}$ (Site clé prolongement), ISO2 = RM (Route mahiboua), ISO3 = SE (Site clé extension), ISO4 = RA (Route Abidjan), ISO5 = CI (CNRA ex idessa), ISO6 = AF (Afridougou), ISO7 = GP (Gagnoa plateau $),$ ISO8 = OD (Odienné); In a column, means followed by the same letter are not significantly different at $5 \%$ (test of DMRT); DMRT: Duncan multiple range test.

\section{DISCUSSION}

The reaction of different isolates of rice yellow mottle virus (RYMV) was studied and the results showed variable reactions on rice cultivars. According to Astiers et al. (2001), different methods were used to know the biological properties of virus, but pathogenicity of the virus is the most important criteria used. Viral replication is the formation of biological viruses during the infection process in the host cell. Virus must first get into the cell before viral replication can occur. In this study, indirect antigen coated plate enzyme linked immunosorbent assay (IACP-ELISA) was performed on infected leaves to determine virus content or 
virus accumulation. Analysis of variance (ANOVA) showed a significant $(\mathrm{p}<0.01)$ interaction between varieties and isolates, for virus content and percentage yield reduction at 28 days after inoculation. The variable reactions of varieties indicated that the RYMV isolates from Gagnoa (Côte d'Ivoire) used in this study were made up of different strains of RYMV. The significant interaction $(p<0.01)$ between varieties and isolates, for virus content and percentage yield reduction indicated that RYMV isolates differ by their virulence, and the varieties by their vertical resistance (Adugna, 2004). Considerable diversity observed in the reaction of the ten rice cultivars to 8 RYMV isolates accumulation in different rice cultivars showed that viral replication depends on the genotype of the rice cultivars and virus isolates involved in these interactions. Similar results were obtained by Onasanya et al. (2004), Sorho et al. (2005) and Issaka et al. (2012). The variability in the response of rice cultivars showed that the RYMV isolates had various levels of pathogenicity. In susceptible varieties, virus content was correlated to yield loss, but few varieties had high virus content meanwhile, yield was not affected. The cultivar Bouaké 189 was susceptible to all isolates used in this study with an important yield loss except isolate 7 . This isolate is less aggressive and virulent than the others isolates. This isolate was collected on upland rice ecology in Gagnoa. Yield loss was evaluated to $27.9 \%$ and it can only infect $50 \%$ of all the cultivars. These results showed that pathogenicity has two components: virulence and aggressiveness. Virulence is defined as the capacity of the pathogen to induce disease. Virulence is also the capacity to overcome resistance by pathogens. This component of pathogenicity favors epidemic progress in the field.

Therefore, the aggressiveness expresses the severity of the diseases (Astier et al.,
2001). In the present study, the isolates $1,3,4$ and 5 have infected more rice cultivars, but isolates 1 and 2 are responsible for the highest yield reduction.

Resistance breaking observed in the field is related to the emergence of new strains of RYMV isolates (Sorho et al., 2005; Traore et al., 2010; Poulicard et al., 2010). Transformation during viral replication can lead to virulent isolates. Thus, virulent isolates were obtained experimentally by amino acid substitution in Vpg protein (Poulicard et al., 2010). Onasanya et al. (2006, 2012), studying RYMV variability in different localities in Côte d'Ivoire, showed the existence of several pathotypes of RYMV. Most interactions observed between isolates of RYMV and varieties was significant using ANOVA test suggesting that the RYMV isolates in most rice localities differ by their virulence (Adugna, 2004). The RYMV isolates differ also by their aggressiveness and were responsible of high yield losses. Sorho et al. (2005) showed that the properties of virulence and aggressiveness of the virus were not linked. Aggressive isolates have a negative impact on plant growth by reducing photosynthesis activity (Soko et al., 2010). In this study the rice cultivars Lac 23, ITA235, FARO11 (OS6), MOROBEREKAN, IR4768615-1-1 could be described as possessing both stable and acceptance levels of resistance to RYMV. Under different rice ecologies in Gagnoa, these cultivars possessed heterogenous viral resistance making them to be more stable and more resistant to stress induced by different isolates of RYMV. The cultivars Gigante did not show compatibility with all isolates while the cultivars Bouaké 189, PNA647F4-56, H234-18-1-1-1 and H23244-1-1 present high compatibility. The resistance genes rymvl-2 of the cultivars Gigante was useful against the different isolates of RYMV (Albar et al., 2006). Isolate 1 from an alternative host Sacciolepis 
africana, was very virulent and aggressive. Therefore, we could say that this alternative host plays an important role in RYMV transmission.

Intensive rice cultivation using the same productive cultivars would be the causes of virulent and aggressive isolates emergence in Gagnoa. Sorho et al. (2005) showed that several propagations of RYMV on the susceptible rice cultivar Bouake 189, favors emergence of virulent isolates. Onasanya et al. (2004) indicated the existence of different pathotypes among the isolates collected from different rice ecosystem in Côte d'Ivoire. The durability of the rice cultivars resistance could be compromised by the existence of different strains of the virus in Gagnoa.

\section{Conclusion}

The interactions in the reaction of the rice genotypes to RYMV isolates suggest the existence of different strains in a restrictive environment. These different strains of RYMV are responsible for yield losses in rice ecosystem of Gagnoa. This information could be useful in the rice breeding program aiming at deployment of RYMV resistant genotypes to different rice ecologies in Gagnoa.

\section{COMPETING INTEREST}

Authors have declared that no competing interests exist.

\section{AUTHOR'S CONTRIBUTIONS}

This work was carried out in collaboration between all authors. Authors SDF, AK designed the study, performed the experiments and wrote the manuscript. Author $\mathrm{SDF}, \mathrm{KTH}$ and KNBC were responsible for data interpretation, statistical analysis and literature searches. Authors TDC, SY and AS carried out the experimental process, helped in experiments and managed the analyses of the study. All the authors red and approved the final manuscript.

\section{REFERENCES}

Abo ME, Alegbejo MD, Sy AA, Misari SM. 2000. An overview of the mode of transmission, host plants and methods of detection of Rice yellow mottle virus. Journal of Sustaineble Agriculture, 17: 19-36. DOI: http://dx.doi.org/ 10.1300/J064v17 n01_04

Adugna A. 2004. Alternate approaches in deploying genes for disease resistance in crop plants. Asian J. Plant Sci., 3: 618623. DOI: http://dx.doi.org/ 10.3923/ajps.2004. 618.623

Albar L, Angratz-reyse R M, Hebrar E, Ndjiondjop MN, Jone M, Ghesquiere A. 2006. Mutations in the $\operatorname{eIF(iso)4G}$ translation initiation factor confer high resistance of rice to rice yellow mottle virus. Plant J., 47: 417-426. DOI: http://dx.doi.org/ 10.1111/j.1365-

313X.2006.02792.x

Allarangaye MD, Traore O, Traore EVS, Millogo RJ, Guinko S, Konate G. 2007. Host range of rice yellow mottle virus in sudano-sahelian Savannahs, Pak. Biol.Sci., 10: 1414-1421. DOI: http://dx.doi.org/10.3923/pjbs.2007.1414. 1421

Amancho NA, Kouassi NK, Diallo HA, Bouet A, Sangare A, Kouadio YJ. 2009. The report of highly resistance breaking isolates of rice yellow mottle virus in Cote d'Ivoire. Afri. J. Plant Sci. Biotechnol., 3: 44-50.

Astier S, Albouy J, Maury Y, Lecoq H. 2001. Principe de virologie végétale: Génome, Pouvoir pathogène, Ecologie des virus, INRA EDN : Paris ; 444 p.

Banwo OO, Alegbojo MD, Abo ME. 2004. Rice yellow mottle virus genus Sobemovirus: A continental problem in Africa. Plant Prot. Sci., 39: 26-36.

Clark MF, Adams RN. 1977. Characteristics of the microplate method of Enzyme Linked Immuno-sorbent Assay for the 
detection of plant virus. Journal of General Virology, 34: 475-483. DOI: http://dx.doi.org/ 10.1099/0022-1317-343-475

Gnanamanickam SS. 2009. Biological Control of Rice Diseases. Springer, The Netherland, $\quad 8$ : $13-42 . \quad$ DOI: http://dx.doi.org/ 10.1007/978-90-4812465-7

Issaka S, Onasanya A, Basso A, Sorho F, Haougui A, Sido AY, Ake S, Fargette D, Sere Y. 2012. Existence of several pathotypes among Rice Yellow Mottle Virus (RYMV) isolates collected in Niger Republic. Trends in Applied Sciences Research, 7: 32-45. DOI: http://dx.doi.org/10.3923/tasr.2012.32.45

Ndjiondjop MN, Brugidou C, Shipping Z, Fargette D, Ghesquiere A, Fauquet CM. 2001. High resistance to rice yellow mottle virus in two cultivated rice cultivars is correlated with cell- to- cell movement. Physiol. Mol. Plant Pathol., 59: $\quad 309-316 . \quad$ DOI: http://dx.doi.org/ 10.1006/pmpp.2001.036 8

Nwilene FN, Traore AK, Assidi AN, Sere Y, Onasanya A,Abo ME. 2009. New records of insect vectors of Rice Yellow Mottle Virus (RYMV) in cote d'ivoire, West Africa. J. Entoml., 6: 198-206. DOI: http://dx.doi.org/ 10.3923/je.2009.198.206

Ochola D, Tusiime G. 2011a. Pathogenicity of rice yellow mottle virus and potential sources of resistance against the disease in Easten Uganda. Asian J. Plant Pathol., 5: 1-15. DOI: http://dx.doi.org/ 10.3923/ajppaj.2011.1.15

Onasanya A, Sere Y, Nwilene F, Abo ME, Akator K. 2004. Reactions and Resistance Status of differential rice genotypes to rice yellow mottle virus, genus sobemovirus in Cote d'Ivoire. Asian Journal of Plant Sciences, 3(6): 718-723. DOI: http://dx.doi.org/ 10.3923/ajps.2004.718.7 23

Onasanya A, Sere Y, Sie M, Akator K, Coulibaly MM, Hamadou A. 2006. Existence of two pathotypes of rice yellow mottle virus, genus Sobemovirus, in Mali. Plant Pathol. J., 5: 368-372. DOI: http://dx.doi.org/ 10.3923/ppj.2006.368.37 2

Onasanya A, Joseph A, Olufolaji DB, Ekperigin MM, Sere Y, Nwilene FE, Kiepe RO, Onasanya A. 2012. RYMV Serological detection in insect vector, distribution and transmission to rice cultivars. Trends in Applied Sciences Research, 7(1): 46-56. DOI: http://dx.doi.org/ 10.3923/tasr.2012.46.56

Onwughalu JT, Abo ME, Okoro JK, Onasanya A, Sere Y. 2010. The effect of rice yellow mottle virus infection on the performance of rice (Oryza sativa L.) relative to time of infection under screenhouse condition. $J$. Applied Sci., 10: 1341-1344. DOI: http://dx.doi.org/10.3923/jas.2010.1341.1 344

Onwughalu JT, Abo ME, Okoro JK, Onasanya A, Sere Y. 2011. Rice Yellow Mottle Virus infection and reproductive losses in (Oryza sativa Linn.) Trend Applied sci. Res., 6: 182-189. DOI: http://dx.doi.org/ 10.3923/tasr.2011.182.189

Poulicard N, Pinel-Galzi A, Hebrard E, Fargette D. 2010. Why Rice yellow mottle virus, a rapidly evolving RNA plant virus, is not efficient at breaking rymvl-2 resistance. Mol Plant Pathol., 11: 145154. DOI: http://dx.doi.org/ 10.1111/j.1364-3703.2009.00582.x

Sere Y, Onasanya A, Akator K, Afolabi A, Abo ME. 2007. Serological Differentiation indice (SDI) and phylogenetic analyses of Rice yellow mottle virus isolates in Cote d'Ivoire. $J$ Biol. Sci., 7: 1147-1154. DOI: 
http://dx.doi.org/10.3923/jbs.2007.1147.1 154

Sere Y, Onasanya A, Nwilene FE, Abo ME, Akator K. 2008a. Potentiel of insect vector screening method for development of durable resistant cultivars to rice yellow mottle virus disease. Int. J. Virol., 4: 4147. DOI: http://dx.doi.org/ 10.3923/ijv.2008.41.47

Soko DF, Sere Y, Ake S. 2010. Effet de l'âge de huit cultivars de riz sur l'expression génétique de la résistance au virus de la panachure jaune du riz. Journal of Applied Biosciences, 25: 1585-1593.

Sorho F, Pinel A, Traore O, Bersoult A, Ghesquiere A, Hebrard E, Konate G, Sere Y, Fargette D. 2005. Durability of natural and transgenic resistances in rice to Rice yellow mottle virus. European Journal of plant pathology, 112: 349-359. DOI: http://dx.doi.org/10.1007/s10658-0056607-5
Thiemélé D, Boisnard A, Ndjiondjop MN, Chéron S, Séré Y, Aké S, Ghesquière A, Albar L. 2010. Identification of a second major resistance gene to rice yellow mottle virus, $R Y M V 2$, in the African cultivated rice species, $O$. Glaberrima. Theor. Applied Genet., 121: 169-179. DOI: http://dx.doi.org/ 10.1007/s00122010-1300-2. Epub 2010 Mar 3.

Traore MD, Traore VSE, Galzi-Pinel A, Fargette D, Konate G, Traore AS, Traore O. 2008. Abiotic transmission of Rice yellow mottle virus through soil and contact between plants. Pac. J. Bio. Sci., 11: 900-904. DOI: http://dx.doi.org/ 10.3923/pjbs.2008.900.904

Traore O, Galzi-Pinel A, Issaka S, Poulard et Aribi J. 2010. The adaptation of rice yellow mottle virus to the eIF(iso) $4 \mathrm{G}$ mediated rice resistance. Virology, 408: 103-108. DOI: http://dx.doi.org/ 10.1016/j.virol.2010.09.007 